\title{
Geochemical analysis and scientific conservation of the exterior surface of the ancient Kedarnath temple, Uttarakhand, India
}

\author{
Vimal Kumar $^{1, *}$, S. S. Panda ${ }^{1}$, B. P. Nauni ${ }^{1}$, Ram Ji Nigam ${ }^{1}$ and \\ Barun K. Mukherjee ${ }^{2}$ \\ ${ }^{1}$ Archaeological Survey of India (Science Branch), 29, New Cantt Road, Dehradun 284 001, India \\ ${ }^{2}$ Wadia Institute of Himalayan Geology, G. M. S. Road, Dehradun 284 001, India
}

Kedarnath temple is situated on the Garhwal Himalayan range near River Mandakini in Rudraprayag, Uttarakhand, India. The temple (more than 1200 years old) was badly affected by devastating floods and landslides during 13-16 June 2013. To protect the aesthetic value of this ancient temple, a systematic scientific conservation has been carried out. The present study describes the geochemical character of the rocks mounted on the temple. It also evaluates weathering trend of the rocks by studying petrography and the analysis of major oxides, using optical microscopy, $\mathrm{X}$ ray fluorescence and $X$-ray diffraction. Petrography and discrimination clusters analysis show that the rock is granitic gneisses in composition and is peraluminous in nature, while the new rock KDN2 sample shows paralkaline character.

Keywords: Ancient temple, conservation, exterior surface, geochemistry, petrography.

Kedarnath temple is situated in Patti malli Kaliphat in parganah Nagpur of British Garhwal (presently Rudraprayag, Uttarakhand, India), in the north lat. $30^{\circ} 44^{\prime} 15^{\prime \prime}$ and east long. $79^{\circ} 6^{\prime} 33^{\prime \prime}$ at an elevation of 11,753 feet amsl. The temple is built on a ridge jutting out at right angles from the snowy range below the Mahapanth peak ${ }^{1}$. Its pinnacle forms the adytum of Shrine. This ancient temple stands near the head of the valley of Mandakini on a level spot. It is a strong building having a neat facade on either side with niches and images ${ }^{1}$. During MayOctober each year, the Kedarnath region becomes overcrowded and remains busy with the Chardham yatra and tourist activities ${ }^{1}$. During 15-17 June 2013, this whole region received sudden cloud bursts, causing incessant rainfall; particularly the Kedarnath area faced devastating flash floods associated with multiphase landslides. The flash floods were so massive that it was called 'Himalayan tsunami ${ }^{2,3}$. Kedarnath temple and its surroundings were badly affected. The Archaeological Survey of India (ASI),

*For correspondence. (e-mail: vimal_drl@yahoo.in)
Ministry of Culture, Government of India (GoI), took up the challenging scientific conservation of the temple.

Building materials for ancient monuments are excavated from the surrounding environment where they are situated at the time of their construction. Daily and seasonal changes in temperature, humidity, wind, snow, rainfall, soluble salts carried by water, biological agents, pollutant gases and particulate matter in the environment introduce in the monuments through physical, chemical and biological processes ${ }^{4}$. Physical weathering is caused specifically by freeze-thaw processes, salt weathering as well as hygric, thermal and wet-dry cycling ${ }^{5}$. Chemical weathering are induced on mineral constituents of the stone by moisture, carbon dioxide and oxygen from the atmospheric air ${ }^{5}$. Various researchers have studied the complex nature of archaeological monuments and stone materials using multiple advanced techniques ${ }^{6,7}$. The present study aims to identify similar rocks on the basis of their geochemical characterization and scientific treatment adopted for chemical conservation of the exterior stone surface of the Kedarnath temple. This study also identifies mineralogical assemblages using X-ray diffraction (XRD) and chemical composition of the rocks through X-ray fluorescence (XRF).

\section{Materials and methods}

\section{Stone specifications}

Four representative rock samples were collected from different parts of Kedarnath temple (Figure 1). The samples were labelled as old KDN1 (OK1, collected from the temple site), old KDN2 (OK2, near the temple site), new KDN1 (NK1, quarry stone), new KDN2 (NK2, quarry stone near the helipad behind the temple).

\section{Analytical procedures}

Microscopic studies: The photomicrographs of rock samples and thin sections were studied using optical 
microscope (Nikon, SMZ-800) with EDF software to determine the rock texture and composition ${ }^{8-10}$.

$X R F$ : The 200 mesh size powdered rock samples were analysed using a high-power X-ray tube of $4 \mathrm{~kW}$ capacity which provides more power wavelength dispersive - XRF (Bruker S-8, USA) ${ }^{6,7,11,12}$.

$X R D$ : The labelled rock samples were powdered and analysed using an XRD system (Panalytical X'pert Pro) through paid instrument facility of Wadia Institute of Himalayan Geology, Dehardun ${ }^{6,711,12}$. XRD pattern was decoded using JCPDS software.

Discriminant function: The discriminant function (DF) values were evaluated using the formula described by Elatikpo et al. ${ }^{13}$. Positive DF values suggest an igneous origin, whereas negative DF values point to sedimentary origin $^{14}$. The formula used is given below

$$
\begin{aligned}
\mathrm{DF} & =10.44-0.21 \mathrm{SiO}_{2}-0.32 \mathrm{Fe}_{2} \mathrm{O}_{3}(\text { total } \mathrm{Fe}) \\
& -0.98 \mathrm{MgO}+0.55 \mathrm{CaO}+1.46 \mathrm{Na}_{2} \mathrm{O}+0.54 \mathrm{~K}_{2} \mathrm{O} .
\end{aligned}
$$

\section{Conservation methods}

The conservation methods to protect and preserve the exterior stone surface of Kedarnath temple were adapted from the literature ${ }^{15-17}$.

\section{Results}

\section{Microscopic studies}

Figure 2 shows microscopic images $(10 \times)$ with surface roughness intensity of all the four types of stone samples collected from the temple site. The megascopic features
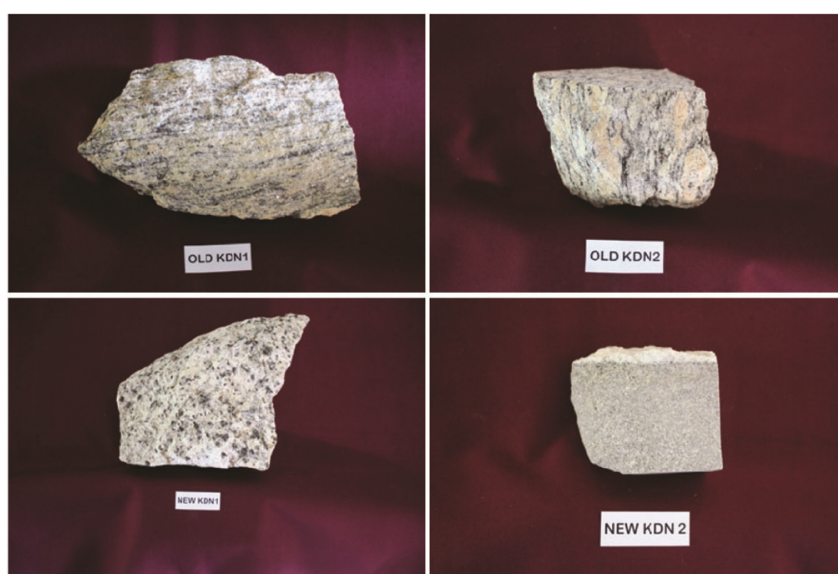

Figure 1. Megascopic features of rock samples collected from Kedarnath temple and nearby areas. show that the stones are dull white in colour with alternate dark and light bands; mineralogically the stones are composed of quartz, feldspar and mica. The rock samples show uneven surface-topography. Figure 3 shows 3D image of surface roughness intensity manifests intense roughness on the surface of tested samples. Figures 4 and 5 show thin-section photomicrographs of the tested rock samples; the photo plates have been recovered both in plane polarized light and crossed nicole. The rocks were essentially composed of quartz, K-feldspar, plagioclase-albite and micas (biotite) along with unidentified accessory minerals. The feeble twining in plagioclase was also noticed during thin-section studies. The mechanical strength and mineralogical texture have also been observed in these images (Figures 4 and 5$)^{8-10}$.
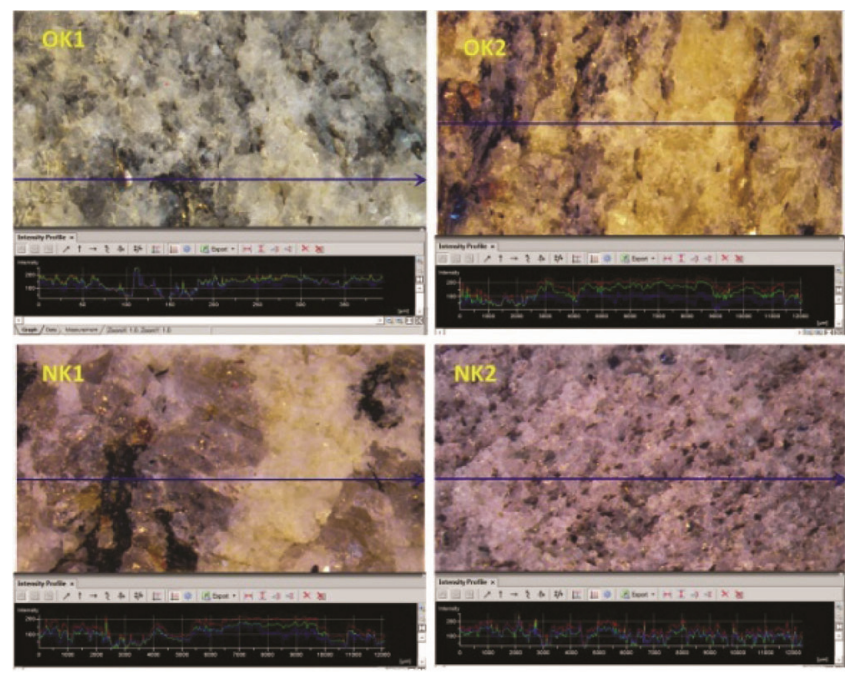

Figure 2. Two-dimensional microscopic images $(10 \times)$ of the studied samples with surface roughness intensity.

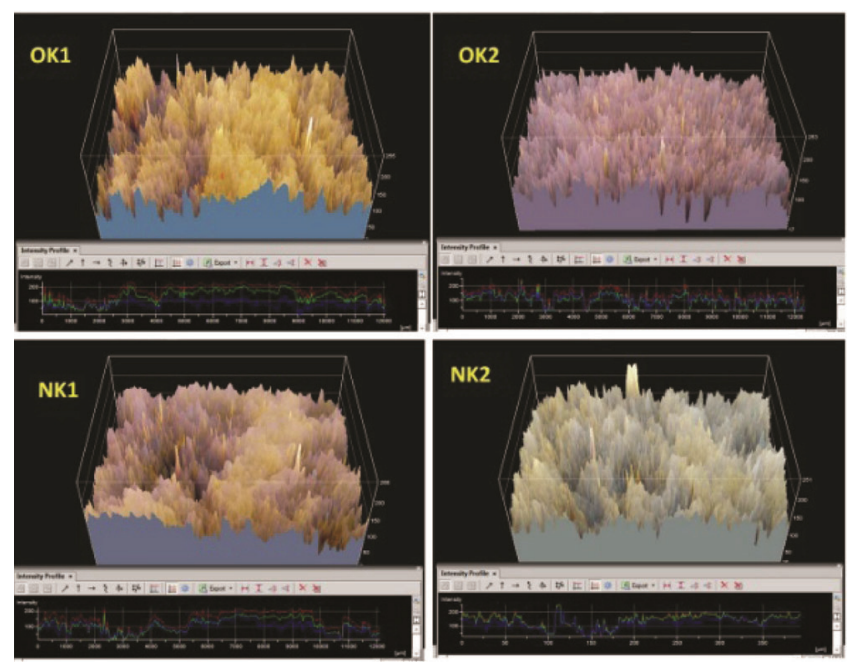

Figure 3. Three-dimensional microscopic images $(10 \times)$ of the studied samples with surface roughness intensity. 
Table 1. Analysis of major oxides of four representative rock samples collected from the temple site

\begin{tabular}{cccccc}
\hline Entry & Major oxides (\%) & Old KDN 1 & Old KDN 2 & New KDN 1 & New KDN 2 \\
\hline 1 & $\mathrm{Na}_{2} \mathrm{O}$ & 3.25 & 2.69 & 3.84 & 2.80 \\
2 & $\mathrm{MgO}$ & 0.40 & 0.44 & 0.39 & 1.32 \\
3 & $\mathrm{Al}_{2} \mathrm{O}_{3}$ & 14.23 & 14.20 & 11.95 & 9.27 \\
4 & $\mathrm{SiO}_{2}$ & 72.19 & 70.88 & 75.44 & 74.67 \\
5 & $\mathrm{P}_{2} \mathrm{O}_{5}$ & 0.18 & 0.30 & 0.14 & 0.11 \\
6 & $\mathrm{~K}_{2} \mathrm{O}$ & 5.23 & 5.69 & 3.20 & 2.82 \\
7 & $\mathrm{CaO}$ & 0.90 & 0.92 & 1.02 & 4.44 \\
8 & $\mathrm{TiO}$ & 0.31 & 0.33 & 0.30 & 0.33 \\
9 & $\mathrm{MnO}_{1}$ & 0.03 & 0.50 & 0.03 & 0.07 \\
10 & $\mathrm{Fe}_{2} \mathrm{O}_{3}$ & 2.32 & 2.98 & 2.73 & 2.64 \\
& $\mathrm{Total}$ & 99.04 & 98.48 & 99.04 & 98.47 \\
\hline
\end{tabular}
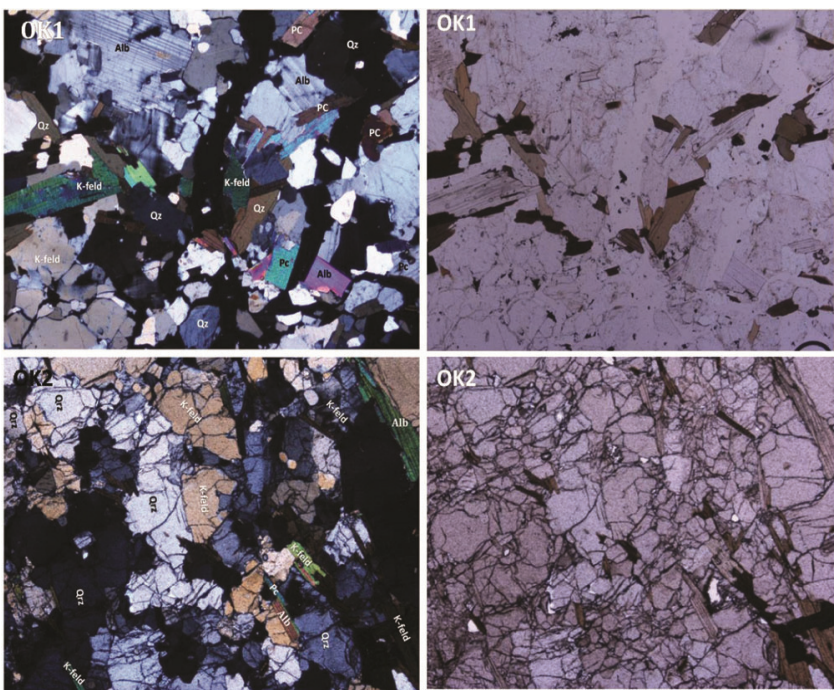

Figure 4. Microscopic image of thin section of OK1 and OK2 samples with crossed nicole and plane polarized light. Scale: View length $\sim 1 \mathrm{~mm}$.
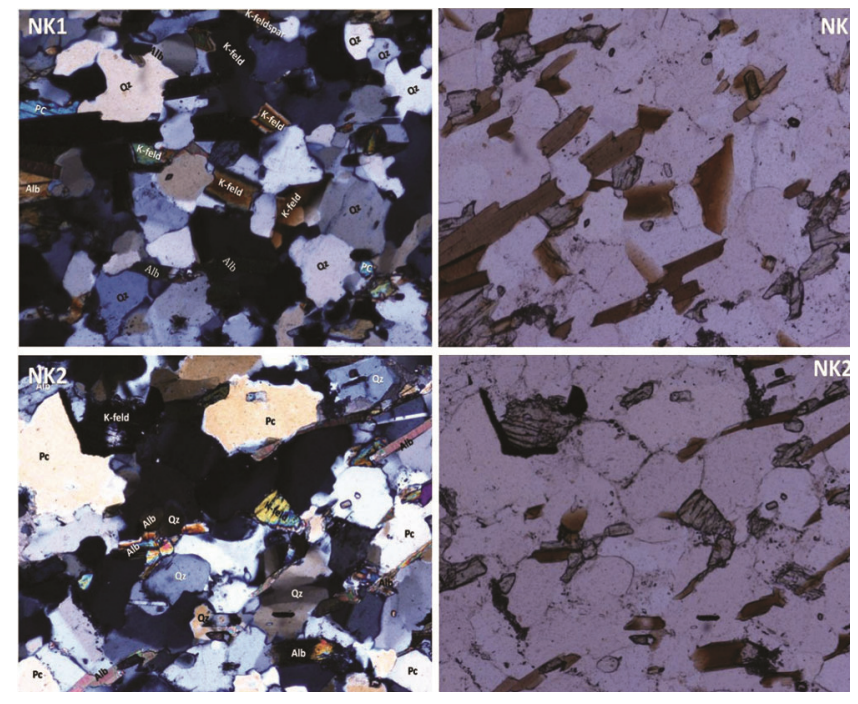

Figure 5. Microscopic image of thin section of NK1 and NK2 samples in crossed nicole and plane polarized light. Scale: View length $\sim 1 \mathrm{~mm}$.

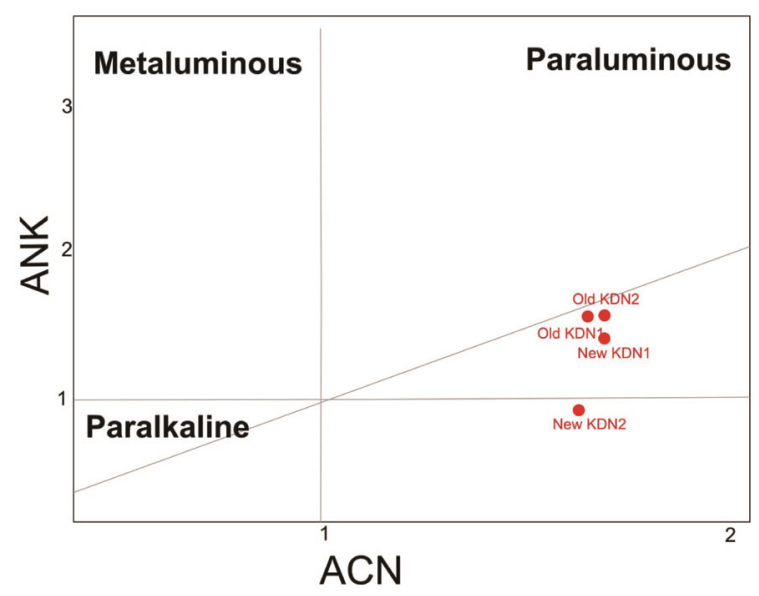

Figure 6. $\mathrm{Al}_{2} \mathrm{O}_{3} /\left(\mathrm{CaO}+\mathrm{Na}_{2} \mathrm{O}+\mathrm{K}_{2} \mathrm{O}\right)$ versus $\mathrm{Al}_{2} \mathrm{O}_{3} /\left(\mathrm{Na}_{2} \mathrm{O}+\mathrm{K}_{2} \mathrm{O}\right)$ plot showing the dominantly peraluminious nature of the analysed rock samples ${ }^{19,20,22}$.

$X R F$ : The chemical composition of four different powdered samples was analysed using XRF. Table 1 shows results of analysis of major oxides. The rock sample contains $\mathrm{SiO}_{2}$, which falls in the higher side in the range of 70.88-75.44 wt $\%$ and low content of $\mathrm{Fe}_{2} \mathrm{O}_{3}$ and $\mathrm{MgO}$ $(2.32-2.98 \mathrm{wt} \%)$ and $(0.39-1.32 \mathrm{wt} \%)$ respectively. Figure 6 shows a plot of $\mathrm{Al}_{2} \mathrm{O}_{3} /\left(\mathrm{CaO}+\mathrm{Na}_{2} \mathrm{O}+\mathrm{K}_{2} \mathrm{O}\right)$ versus $\mathrm{Al}_{2} \mathrm{O}_{3} /\left(\mathrm{Na}_{2} \mathrm{O}+\mathrm{K}_{2} \mathrm{O}\right)$ for the data obtained from XRF results.

XRD: Figures 7 and 8 show the XRD patterns of new and old rock samples respectively. The new KDN1 is mainly composed of quartz (score 52), albite (score 32), orthoclase (score 24), anthrolite (score 20) and K-feldspar (score 21) whereas the new KDN2 has quartz (score 51), albite (score 31), orthoclase (score 15), anorthite (score 21) and Na-feldspar (score 18). Quartz (score 57), albite (score 22), orthoclase (score 21) and K-feldspar (score 19) were present in the old KDN1, whereas quartz (score 53), albite (score 18), orthoclase (score 18) and anorthite (score 17) were reported in the old KDN2. 
$D F$ : All four samples showed positive DF values, indicating that the rocks were igneous in origin (Table 2). The analysed rock samples were poor in ferromagnesium content $\left(\mathrm{Fe}_{2} \mathrm{O}_{3}+\mathrm{MgO}+\mathrm{TiO}_{2}\right)$. For protolith identification, the rock samples were determined using a $\mathrm{DF}$ in case the $\mathrm{MgO}<6 \%$ and $\mathrm{SiO}_{2}<90 \%$ for all quartzofeldspathic rock $\mathrm{k}^{13,14}$.

\section{Discussion}

$\mathrm{XRF}$ results show that $\mathrm{Na}$ is consistently less than $\mathrm{K}$ in the new KDN1 and KDN2 samples. Alumina $\left(\mathrm{Al}_{2} \mathrm{O}_{3}\right)$ content is generally within the same range (9.27$14.23 \mathrm{wt} \%$ ) for all the analysed samples. However, few samples show increasing $\mathrm{Al}_{2} \mathrm{O}_{3}$, and decreasing $\mathrm{SiO}_{2}$
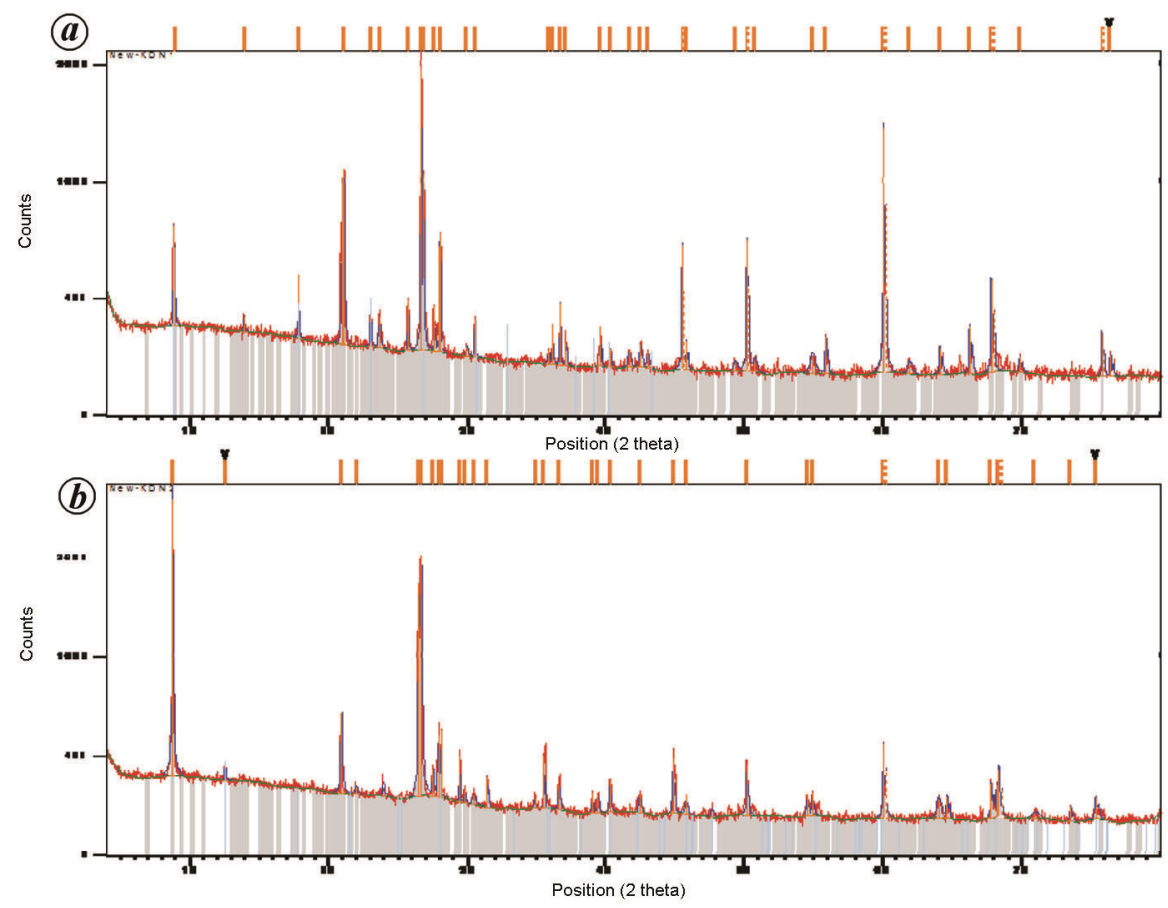

Figure 7. X-ray diffraction (XRD) pattern of the new $(\boldsymbol{a}) \mathrm{KDN} 1$ and $(\boldsymbol{b}) \mathrm{KDN} 2$ rock powder samples of the temple with theta spacing.
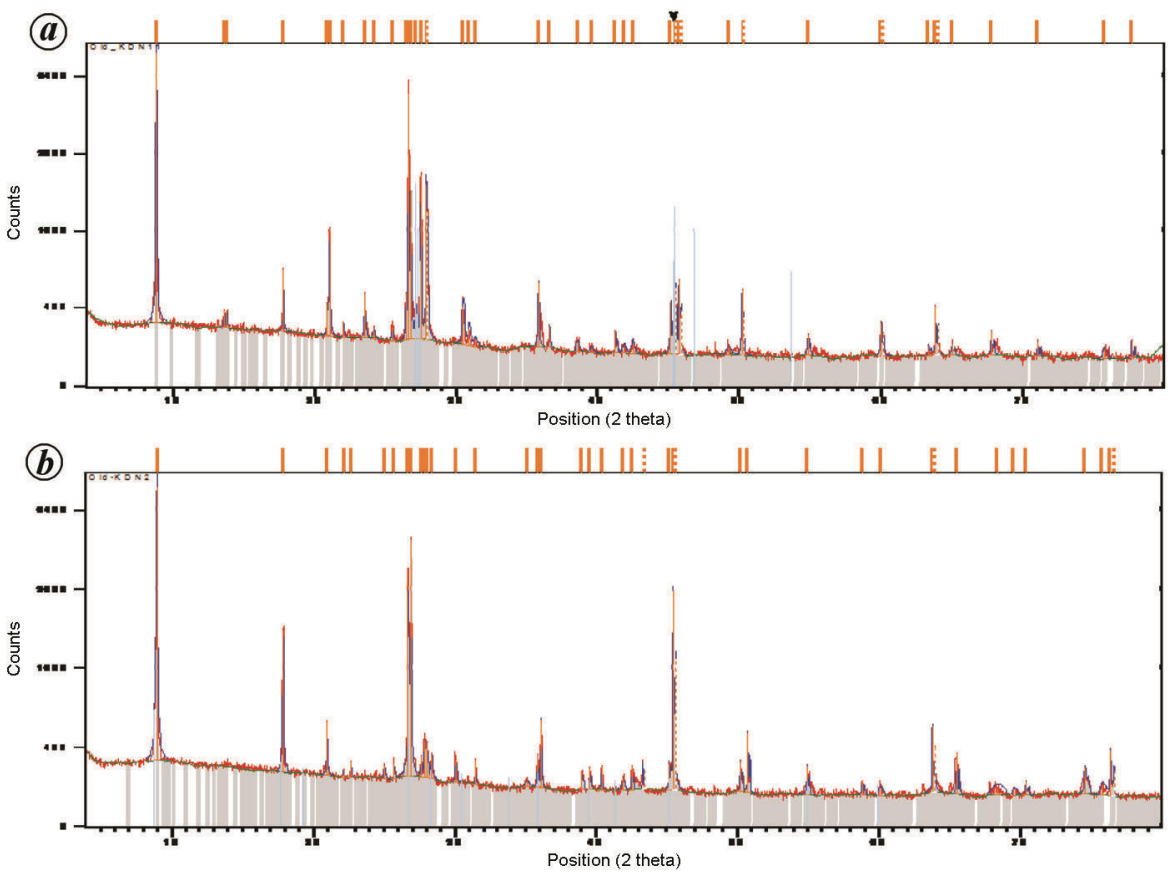

Figure 8. XRD pattern of old (a) KDN1 and (b) KDN2 rock powder samples of the temple with theta spacing. 
Table 2. Calculated discriminant function (DF) of four representative rock samples collected from the temple site

\begin{tabular}{llcccc}
\hline Entry & Analyte (\%) & Old KDN 1 & Old KDN 2 & New KDN 1 & New KDN 2 \\
\hline 1 & $\mathrm{SiO}_{2}$ & 72.19 & 70.38 & 75.44 & 74.67 \\
2 & $\mathrm{Fe}_{2} \mathrm{O}_{3}$ & 2.32 & 2.98 & 2.64 & 2.64 \\
3 & $\mathrm{MgO}$ & 0.40 & 0.44 & 0.39 & 1.32 \\
4 & $\mathrm{CaO}$ & 0.90 & 0.92 & 1.02 & 4.44 \\
5 & $\mathrm{Na}_{2} \mathrm{O}$ & 3.25 & 2.69 & 3.84 & 2.80 \\
6 & $\mathrm{~K}_{2} \mathrm{O}$ & 5.23 & 5.69 & 3.20 & 2.82 \\
7 & $\mathrm{DF}$ & 2.20 & 1.78 & 1.17 & 1.24 \\
\hline
\end{tabular}

content with systematic increase in $\mathrm{CaO}$ and $\mathrm{Na}_{2} \mathrm{O}$. These data suggest that the rocks were derived from a quartzofeldspathic (granitic) source and the geochemical trends match with the characteristics of Archaeon granitic rocks ${ }^{18,19}$. The non-variability of the alumina $\left(\mathrm{Al}_{2} \mathrm{O}_{3}\right)$ in the entire samples were analysed and fall in the range of 9.27-14.23 $\mathrm{wt} \%$, which suggests a calc-alkaline affinity. This could also be due to their low Fe-Mg-bearing silicate mineral. Representative major oxides of all four samples were almost similar to gneiss-1 and gneiss-2 which were reported by Hussain et al. ${ }^{20}$ and Adegbuyi et $a l .{ }^{21}$. All tested samples exhibit peraluminous character, except the new KDN 2 which shows peralkaline character. This was confirmed by the methods reported in the literature $^{19,21,22}$ (Figure 6).

Hard minerals like quartz and albite show huge proportions and data of major oxides of all tested samples indicate granitic gniess ${ }^{23}$ in nature with peraluminous characters and show similar results as reported by Rutland $^{24}$. Quartz, the major constituent in all the four samples, showed higher resistance with respect to pressure, temperature and deformation. The variations in temperature exert significant influence on the disintegration of rocks. In the Kedarnath area during daytime the rocks get heated up by the high-intensity sunrays, causing expansion, while at the night, the temperature falls to sub-zero levels, causing cooling, which results in contraction of the rocks. The rapid physical changes due to expansion and contraction exerted by the stones of the ancient Kedarnath temple decays very easily and crumbles since the rock is a bad conductor of heat ${ }^{25}$. It was also observed that minerals within the rocks vary in their rate of expansion and contraction according to their composition and chemical characteristics. The cubical expansion of quartz is twice that of feldspar ${ }^{26}$. Dark-coloured rocks are subjected to fast changes with temperature compared to lightcoloured rocks ${ }^{26}$. The differential expansion of minerals on a rock surface generates stress between the heated surface and cooled unexpanded parts, resulting in fragmentation of rocks ${ }^{26}$. However, the presence of less amount of moisture content and water shows the small flexibility of minerals which prevents brittleness and surface stress of the rocks. Under extreme weather conditions, rainfall influences chemical weathering. It controls the moisture supply for chemical reactions; this eliminates soluble constituents of the minerals ${ }^{27}$. Studies have shown that Kfeldspar breaks down and forms secondary clay minerals such as illite and kaolinite under extreme weathering conditions $^{28-35}$. The weathering of feldspar is represented as follows

$$
\begin{aligned}
& \text { Feldspar } \rightarrow \text { illite } \rightarrow \text { kaolinite }{ }^{28} . \\
& 2 \mathrm{KI} \mathrm{AlSi}_{3} \mathrm{O}_{8}+2 \mathrm{H}_{2} \mathrm{O}+\mathrm{CO}_{2} \rightarrow \\
& \text { Feldspar } \\
& \mathrm{Al}_{2} \mathrm{Si}_{2} \mathrm{O}_{5}(\mathrm{OH})_{4}+\mathrm{K}_{2} \mathrm{CO}_{3}+4 \mathrm{SiO}_{2} \text {, } \\
& \text { Kaolinite } \\
& 6 \mathrm{~K}\left(\mathrm{AlSi}_{3} \mathrm{O}_{8}\right)+4 \mathrm{H}_{2} \mathrm{O}+4 \mathrm{CO}_{3} \rightarrow \\
& \text { Orthoclase } \\
& \mathrm{K}_{2} \mathrm{Al}_{4}\left(\mathrm{Si}_{6} \mathrm{Al}_{2} \mathrm{O}_{20}\right)(\mathrm{OH})_{4}+12 \mathrm{SiO}_{2}+4 \mathrm{~K}^{+}+4 \mathrm{HCO}_{3} \text {. } \\
& \text { Illite } \\
& 2 \mathrm{KAl}_{5} \mathrm{Si}_{7} \mathrm{O}_{20}(\mathrm{OH})_{4}+2 \mathrm{H}_{2} \mathrm{O}+2 \mathrm{CO}_{3}+13 \mathrm{H}_{2} \mathrm{O} \rightarrow \\
& \text { Illite } \\
& 5 \mathrm{Al}_{2} \mathrm{Si}_{2} \mathrm{O}_{5}(\mathrm{OH})_{4}+4 \mathrm{H}_{4} \mathrm{SiO}_{4}+2 \mathrm{~K}+2 \mathrm{HCO}_{3} \text {. } \\
& \text { Kaolinite }
\end{aligned}
$$

These types of weathering trends were not found in the tested samples of Kedarnath temple. XRD studies reveal that quartz, albite, orthoclase, anthroite and K-feldspar are the main primary minerals in all sample profiles. These minerals are observed mainly in less-weathered samples.

\section{Conservation issues and treatment}

The exterior stone surface of Kedarnath temple had become blackish due to deposition of sandy dust, dirt and dried vegetation and micro-vegetation growth under extreme cold weather conditions. Sand and thick dust layers were redeposited on the exterior surface of the temple during and after the natural disaster of June 2013 (Figure 9). These depositions provided favourable 


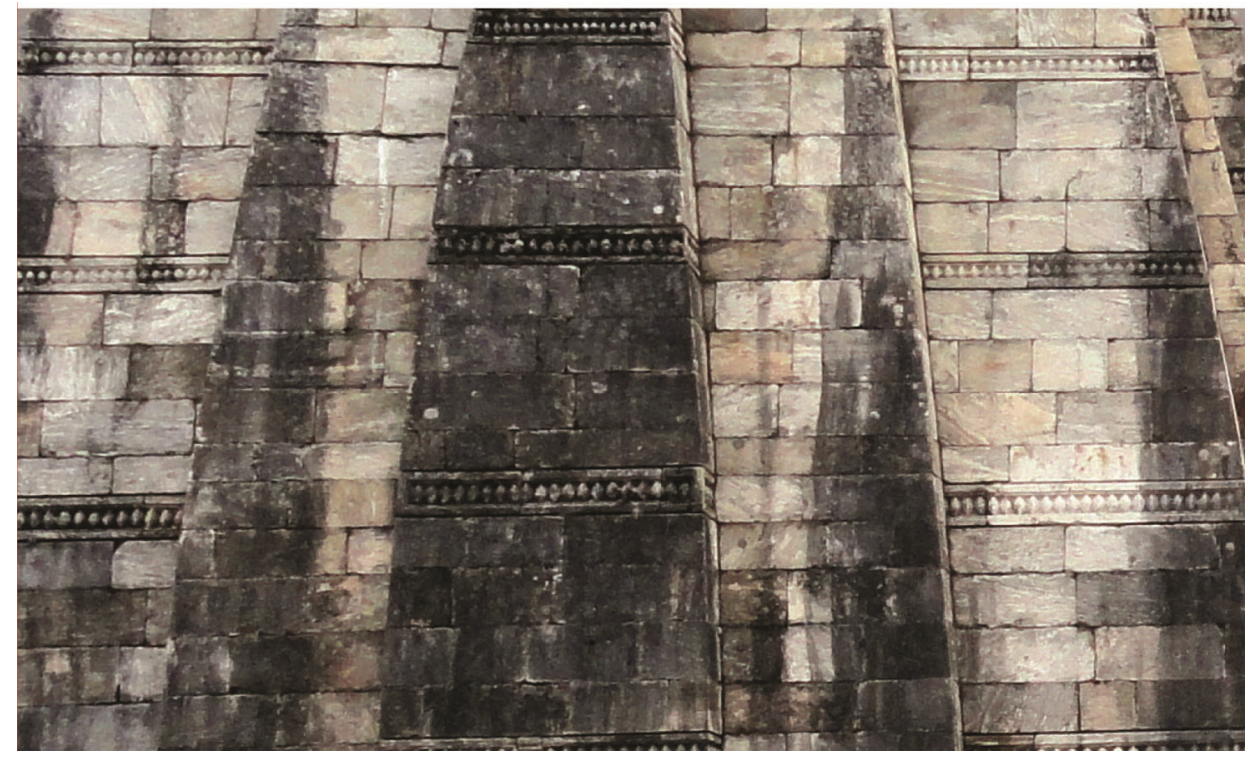

Figure 9. Blackish biofilm growing on the exterior surface of the temple after the flash floods encountered.

conditions for the growth of small insects on the stone surface. They also tarnished the aesthetic value of the temple. Such biogenic and micro-vegetation growth secretes plant acids which digest major oxides of the stones, and cause weathering of the stone surface ${ }^{17}$.

The layers of dust, dirt and micro-vegetation growth were manually removed by applying $2-3 \%$ solution of suitable mild base with non-ionic detergent with the help of soft nylon brushes. A $2 \%$ aqueous antimicrobial solution was sprayed on the clean and dried surface of the temple to prevent further growth of micro-vegetation ${ }^{15-17}$.

\section{Conclusion}

The present study shows that the analysed rock samples are granitic gneiss in nature with peraluminous characters, whereas the new KDN2 sample shows paralkaline character. The old KDN1 sample acts as a reference and the remaining two samples show similar geochemical properties. The conservation efforts are essential to protect and preserve the aesthetic value of Kedarnath temple and preserve its 1200-year-old ancient heritage. The conservation has drastically enhanced the aesthetic beauty of the temple. Thus, this study has importance for the preservation and protection of ancient monuments.

Disclosure statement: The authors report no potential conflict of interest.

1. Atkinson, E. T., Kedarnath. In The Himalayan Gazetter, Vol. III, Part II, Cosmo Publication, Delhi, 1973, pp. 556-557.

2. Das, P. K., The Himalayan tsunami - cloudburst, flash flood and death toll: a geographical postmortem. J. Environ. Sci. Toxicol. Food Technol., 2013, 7(2), 33-45.
3. Durga Rao, K. H. V., Venketshwar Rao, V., Dadhwal, V. K. and Diwakar, P. G., Kedarnath flash floods: a hydrological and hydraulic simulation study. Curr. Sci., 2014, 106(4), 598-603.

4. Caner-Saltık, E. N., Atmospheric weathering of historic monuments and their related conservation issues. MATEC Web Conf., 2018, 149, 01009.

5. Siegesmund, S., Weiss, T. and Vollbrecht, A., Natural stone, weathering phenomena, conservation strategies and case studies: introduction, 2016; http://sp.lyellcollection.org

6. Lombillo, I., Thomas, C., Villegas, L., Fernández-Álvarez, J. P. and Norambuena-Contreras, J., Mechanical characterization of rubble stone masonry walls using non and minor destructive tests. Constr. Build. Mater., 2013, 43, 266-277.

7. Panda, S. S., Mohapatra, P. K., Chaturvedi, R. K. and Kar, S. K., Chemical analysis of ancient mortar from excavation sites of Kondapur, Andhra Pradesh, India to understand the technology and ingredients. Curr. Sci., 2013, 105(6), 837-842.

8. Akesson, U., Stigh, J., Lindqvist, J. E. and Göransson, M., The influence of fliation on the fragility of granitic rocks, image analysis and quantitative microscopy. Eng. Geol., 2003, 68(3-4), 275288.

9. López-Arce, P., Varas-Muriel, M. J., Fernández-Revuelta, B., Álvarez de Buergo, M., Fort, R. and Pérez-Soba, C., Artificial weathering of Spanish granites subjected to salt crystallization tests: surface roughness quantification. Catena, 2010, 83(2-3), 170-185.

10. Freire-Lista, Martín, D., Fort, R. and Varas-Muriel, M. J., Thermal stress-induced microcracking in building granite. Eng. Geol., 2016, 206, 83-93.

11. LA Tour, T. E., Analysis of rocks using X-ray fluorescence spectrometry. Rigaku J., 1989, 6(1), 3-9.

12. Figueiredo, M. O., Silva, T. P. and Veiga, J. P., Analysis of degradation phenomena in ancient, traditional and improved building materials of historical monuments. Appl. Phys. A, 2008, 92, 151-154.

13. Elatikpo, S. M., Danbatta, U. A. and Najime, T., Geochemistry and petrogenesis of gneisses around Kafur-Yari Bori_Tsiga area within the Malumfashi Schist Belt, North Western Nigeria. J. Environ. Earth Sci., 2013, 3(7), 171-180.

14. Shaw, D. M., Petrology, mineralogy, and geochemistry of Falkland Plateau the basement rock, site 330 deep sea drilling project. Initial Rep., 1972, 36, 893-921. 
15. Plenderlith, H. J. and Werner, A. E., The Conservation of Antiquities and Works of Art and Repair, Oxford University Press, London, UK, 1979, 2nd edn, pp. 306-307.

16. Agrawal, O. P., Conservation of cultural heritage. The challenges before us. J. Indian Mus., 1993, 49, 94.

17. ASI, Indian archaeology 2011-12 - a review. Director General, Archaeological Survey of India, New Delhi, 2016, pp. 1-317.

18. Oyinloye, A. O., Geology and geotectonic setting of the basement complex rocks in south western Nigeria: implications on provenance and evolution. Earth and Environmental Sciences (ed. Dar, I. A.), In Tech Publisher, Croatia, 2011, pp. 97-118.

19. Shand, S. J., Eruptive Rocks: Their Genesis, Composition, Classification, and their Relation to Ore-Deposits with a Chapter on Meteorite, John Wiley, New York, USA, 1943.

20. Hussian, M. F., Mondal, M. E. A. and Ahmad, T., Geochemistry of basement gneisses and gneissic enclave from Bastar craton: geodynamic implication. Curr. Sci., 2004, 86(11), 1543-1547.

21. Adegbuyi, O., Ogunyele, A. C. and Akinyemi, O. M., Petrology and geochemistry of basement gneissic rocks around Oka-Akoko, southwestern Nigeria. Mal. J. Geosci., 2018, 2(2), 11-16.

22. Maniar, P. D. and Piccoli, P. M., Tectonic discrimination of granitoids. Geol. Soc. Am. Bull., 1989, 101, 635-643.

23. Singh, S. and Murthy, P. S. K., Gneisses - strengths and mineralogical compositions. Int. J. Innov. Res. Sci., Eng. Technol., 2016, 5(3), 3658-3663.

24. Rutland, R. W. R. and Sutherland, D. S., The chemical composition of granitic gneisses and sparagmitic metasediments in the Glomfjord region, Northern Norway. Norsk Geol. Tidssrift, 1968, 48, 365-380.

25. Buckley, E. R., The properties of building stones and methods of determining their value (studies for students). J. Geol., 1900, 8(2), $160-185$.

26. Agriculture information Bank, Introduction soil science; www.agriinfo.in/page (retrieved on 18 July 2017).

27. Jenny, H., Factors in Soil Formation, McGraw Hill, New York, USA, 1941, p. 271.
28. Islam, M. R., Stuart, R., Risto, A. and Vesa, P., Mineralogical changes during intense chemical weathering of sedimentary rocks in Bangladesh. J. Asian Earth Sci., 2002, 20, 889-901.

29. Ehlmann, A. J., Clay mineralogy of weathered products and river sediments. J. Sediment. Petrol., 1968, 2, 885-894.

30. Wilson, M. J., Chemical weathering of some primary rock forming minerals. Soil Sci., 1975, 119(5), 349-355.

31. Eswaran, H. and Heng, Y. Y., The weathering of biotite in a profile on gneiss in Malaysia. Geoderma, 1976, 16(1), 9-20.

32. Eswaran, H. and Bin, W. C., A study of a deep weathering profile on granite in Peninsular Malaysia. II. Mineralogy of the clay, silt, and sand fractions. Soil Sci. Soc. Am. J., 1978, 42, 149-153.

33. Eswaran, H. and Bin, W. C., A study of a deep weathering profile on granite in Peninsular Malaysia. III. Alteration of feldspars. Soil Sci. Soc. Am. J., 1978, 42, 154-158.

34. Paven, M. J., Fedoroff, N. and Robert, M., Alteration meteorique des biotites on Algerie. Geoderma, 1981, 26, 287-309.

35. Novikoff, A., Tawlassou, G., Gac, J. Y., Bourgeat, F. and Tardy, Y., Alteration des biotites dans les arenes des pays temperes, tropicaux et equatoriaux. Sci. Geol., 1972, 25, 287-305.

ACKNOWLEDGEMENTS. We thank the Superintending Archaeologist, Dehradun circle, Dehradun for support during the conservation work, and all the active teams of the science branch, Archaeological Survey of India, who were actively worked for Conservation work of Kedarnath temple. We also thank the Joint Director General (Conservation), Archaeological Survey of India, Dehradun (ASI) for the constructive suggestions and support during the project, and the Director General, New Delhi and Ministry of Culture, Government of India, for financial and administrative support for the project.

Received 31 March 2020; accepted 6 April 2021

doi: $10.18520 / \mathrm{cs} / \mathrm{v} 121 / \mathrm{i} 4 / 560-566$ 